Article

\title{
Preparation of Antioxidant Peptide by Microwave- Assisted Hydrolysis of Collagen and Its Protective Effect Against $\mathrm{H}_{2} \mathrm{O}_{2}$-Induced Damage of RAW264.7 Cells
}

\author{
Yan $\mathrm{Li}^{1}{ }^{1}$, Jie Li ${ }^{1}$, Sai-Jun Lin ${ }^{2}$, Zui-Su Yang ${ }^{1}$ and Huo-Xi Jin ${ }^{1, *}$ \\ 1 Zhejiang Provincial Engineering Technology Research Center of Marine Biomedical Products; School of Food \\ and Pharmacy, Zhejiang Ocean University, Zhoushan 316022, China; m18625623399@163.com (Y.L.); \\ lijie1749@126.com (J.L.); abc1967@126.com (Z.-S.Y.) \\ 2 Hangzhou Institute for Food and Drug Control, Hangzhou 310052, China; saijunlin@126.com \\ * Correspondence: jinhuoxi@zjou.edu.cn; Tel.: +86-580-255-2395
}

Received: 16 October 2019; Accepted: 12 November 2019; Published: 14 November 2019

\begin{abstract}
Antioxidant peptides have elicited interest for the versatility of their use in the food and pharmaceutical industry. In the current study, antioxidant peptides were prepared by microwave-assisted alkaline protease hydrolysis of collagen from sea cucumber (Acaudina molpadioides). The results showed that microwave irradiation significantly improved the degree of hydrolysis of collagen and the hydroxyl radical (OH.) scavenging activity of hydrolysate. The content and $\mathrm{OH}$. scavenging activity of collagen peptides with molecular weight $\leq 1 \mathrm{kDa}\left(\mathrm{CP}_{\mathrm{S}}\right)$ in the hydrolysate obtained at $250 \mathrm{~W}$ increased significantly compared with the non-microwave-assisted control. $\mathrm{CP}_{\mathrm{S}}$ could scavenge $\mathrm{OH} \cdot$ and 2,2-diphenyl-1-picrylhydrazyl (DPPH) radical in a dose-dependent manner. The scavenging activity of $\mathrm{OH}$ - and DPPH radical was $93.1 \%$ and $41.2 \%$, respectively, at $\mathrm{CP}_{\mathrm{S}}$ concentration of $1 \mathrm{mg} / \mathrm{mL}$. $\mathrm{CP}_{\mathrm{S}}$ could significantly promote RAW264.7 cell proliferation and reduce the Reactive Oxygen Species (ROS) level of $\mathrm{H}_{2} \mathrm{O}_{2}$-induced damage in RAW264.7 cells in a dose-dependent manner. Furthermore, all $\mathrm{CP}_{\mathrm{S}}$-treated groups exhibited an increase in superoxide dismutase (SOD) and glutathione peroxidase (GSH-Px) and a decrease in malondialdehyde (MDA) level compared with the control. These results showed that $\mathrm{CP}_{\mathrm{S}}$ could effectively protect RAW264.7 cells from $\mathrm{H}_{2} \mathrm{O}_{2}$-induced damage, implying the potential utilization of $\mathrm{CP}_{\mathrm{S}}$ as a natural antioxidant for food and pharmaceutical applications.
\end{abstract}

Keywords: Acaudina molpadioides; antioxidant peptides; microwave-assisted hydrolysis; oxidative stress protection

\section{Introduction}

Bioactive peptides are short peptides with some bioactive functions, such as antioxidant, antimicrobial, antitumor, or antihypertensive activity. Bioactive peptides have been widely used in health-food, nutraceuticals, and pharmaceutical preparations due to their significant biological functions and efficient absorption [1]. As one of several promising bioactive peptides, antioxidant peptides have become a topic of great interest because of the association between many human diseases and oxidative stress [2]. When humans are subjected to oxidative stress, large amounts of reactive oxygen species (ROS) are produced. Abundant quantities of ROS (superoxide, hydrogen peroxide, and hydroxyl) tend to react with biological molecules, such as protein and DNA, often leading to liver disease, heart disease, and cancer because of oxidative damage of cells [3,4]. ROS-induced oxidative cell damage is usually accompanied by an increase in lipid peroxides [5]. It was known that 
malondialdehyde (MDA) is the major secondary metabolite of lipid peroxidation induced by ROS. The content of MDA is a marker of lipid peroxidation and the degree of cell damage [6]. The superoxidase dismutase (SOD) and glutathione peroxidase (GSH-Px) are the major antioxidant enzymes, which play a key role in protecting cells from oxidative damage [7]. Antioxidants can protect the body from damage by removing excess ROS, reducing the MDA, and improving the activities of SOD and GSH-Px. Therefore, as a natural antioxidant, antioxidant peptides have great potential of utilization in pharmaceutical industries.

At present, antioxidant peptides are mainly obtained by separation and purification directly from the plant or animal tissues, chemical synthesis, microbial fermentation, or enzymatic hydrolysis of protein. However, the separation and purification of antioxidant peptides directly from the plant or animal tissues, and fermentation products are expensive. Chemical synthesis of peptides also requires sophisticated and expensive equipment and reagents, and the chemical reagents involved may be harmful to humans and/or cause environmental pollution. Therefore, enzymatic digestion of protein has been the most common method for preparation of antioxidant peptides due to the simplicity, safety, low-cost, and sustainability of the approach [8]. Collagen is an important structural protein rich in hydroxyproline, which has been employed in food and medical applications for decades with excellent biocompatibility and safety $[9,10]$. For example, the collagens from echinoderms (sea urchin, starfish, and sea cucumber) can be used to develop collagen barrier-membranes for guided tissue regeneration due to the good mechanical performances [11]. However, the large molecular weight of the compound creates barriers in absorption and utilization in the body. Therefore, collagen peptides, smaller proteins hydrolyzed from collagen, have received increasing attention because of their physicochemical properties and biological activity [12-14]. However, one of the limitations of the collagen peptides production process is the length of time required in conventional hydrolysis methods due to its dense fiber structure [8]. This limitation can potentially be overcome by using microwave assisted hydrolysis. Studies have shown that microwaves cause different biological and chemical effects depending, among other factors, upon strength, frequencies and length of exposure [15]. Microwave radiation penetrates into the interior of the protein molecule, exposing the hidden enzymatic sites and enabling a more thorough hydrolysis [16]. Microwave-assisted enzymatic hydrolysis of protein can, therefore, significantly reduce the overall hydrolysis time and increase the yield of peptide by intensifying molecular movements and collisions [8]. Previous studies had also demonstrated microwave-assisted enzymatic hydrolysis to be one of the most effective methods to prepare peptides $[8,17,18]$.

Sea cucumbers, of which more than 1400 species exist around the world, are important marine resources of protein containing high amounts of collagen in their body wall [19]. Several researchers have reported the development and characteristics of various collagens from sea cucumbers [20-23]. The common sea cucumber, Acaudina molpadioides, is widely distributed in East China Sea, especially in the coastal areas of Ningbo and Zhoushan. Traditionally, due to the lack of key technologies for industrialization, Acaudina molpadioides resources have not been utilized to their potential and continue to sell for a low price. The preparation of collagen peptides using Acaudina molpadioides has great potential due to the good biological function of collagen peptides and inexpensive raw materials of Acaudina molpadioides [24]. Studies have shown that collagen peptides of sea cucumber have a demonstrated ability to scavenge free radicals and other peroxides [25]. In previous studies, we had prepared an antioxidant peptide from collagen of Acaudina molpadioides (ASC-Am) by microwave-assisted neutral protease hydrolysis [26]. Different proteases hydrolyze different sites of the protein to produce peptides of different amino acid sequences. Therefore, in this study, we focus on production of antioxidant peptides from ASC-Am by microwave-assisted alkaline protease hydrolysis. Furthermore, the protective effect of antioxidant peptides against peroxide $\left(\mathrm{H}_{2} \mathrm{O}_{2}\right)$ - induced damage of RAW264.7 cells was investigated by measuring cell proliferation, ROS, MDA, SOD, and GSH-Px levels. 


\section{Results and Discussion}

\subsection{Effect of Microwave Assisted on Alkaline Protease Hydrolysis of ASC-Am}

The effect of microwave power on $\mathrm{OH}$. scavenging activity of hydrolysate by alkaline protease digestion of ASC-Am was investigated (Figure 1). The results demonstrated that $\mathrm{OH}$. scavenging activities were significantly improved at all tested microwave powers (50-300 W) as compared to non-microwave assisted hydrolysis. The enhanced $\mathrm{OH}$. scavenging activity when the microwave power increased from 50 to $250 \mathrm{~W}$ suggested that the higher microwave power enabled the higher probability of contact between ASC-Am and alkaline protease, resulting in more small peptides with antioxidant activity. However, excessive molecular collisions cause the denaturation of alkaline protease, which may make the $\mathrm{OH}$ - scavenging activity begin to decrease when the microwave power continues to increase to $300 \mathrm{~W}$. The maximum $\mathrm{OH}$. scavenging activity was observed at $250 \mathrm{~W}$ of microwave power, which increased from $70.3 \%$ in non-microwave assisted to $96.2 \%$ in this treatment. Therefore, $250 \mathrm{~W}$ was selected as the optimal power for microwave-assisted alkaline protease digestion of ASC-Am.

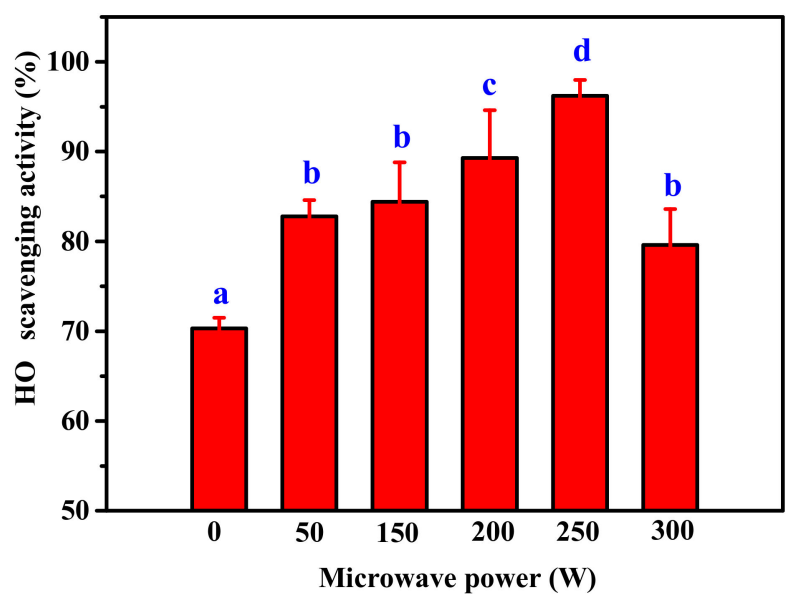

Figure 1. Effect of microwave power on $\mathrm{OH}$ scavenging activity of collagen hydrolysate. The concentration of hydrolyzed product was $2 \mathrm{mg} / \mathrm{mL}$. Values with different letters are significantly different $(p<0.05)$.

In addition, we investigated the content and molecular weight distribution of the peptides in hydrolyzate under microwave assisted digestion with $250 \mathrm{~W}$. As shown in Table 1, compared with $0 \mathrm{~W}$, the total content of $\mathrm{CP}_{\mathrm{L}}$ at $250 \mathrm{~W}$ decreased, but the content of $\mathrm{CP}_{\mathrm{M}}$ and $\mathrm{CP}_{\mathrm{S}}$ increased by $48 \%$ and $30.2 \%$, respectively. Furthermore, the proportions of $\mathrm{CP}_{\mathrm{M}}$ and $\mathrm{CP}_{\mathrm{S}}$ in hydrolyzate obtained at $250 \mathrm{~W}$ were both higher than those at $0 \mathrm{~W}$. These results suggested that microwave assisted hydrolysis can significantly promote the breakdown of ASC-Am into smaller molecular weight peptides. The results of this study were similar to those of Uluko et al. (2015), which showed that the hydrolyzed product under microwave irradiation increased by $184.9 \%$ compared to the control [27].

Table 1. Effect of microwave-assisted hydrolysis of ASC-Am on peptide content and molecular weight distribution.

\begin{tabular}{ccccc}
\hline \multirow{2}{*}{ Hydrolysates } & \multicolumn{2}{c}{ Content (\%) } & \multicolumn{2}{c}{ Mw Distribution (\%) } \\
& $\mathbf{0 ~ W}$ & $\mathbf{2 5 0 ~ W}$ & $\mathbf{0 ~ W}$ & $\mathbf{2 5 0} \mathbf{~ W}$ \\
\hline $\mathrm{CP}_{\mathrm{L}}(\mathrm{Mw}>5 \mathrm{kDa})$ & 100 & $90.3 \pm 4.3$ & $21.7 \pm 2.1$ & $15.7 \pm 1.5$ \\
$\mathrm{CP}_{\mathrm{M}}(1 \mathrm{kDa}<\mathrm{Mw} \leq 5 \mathrm{kDa})$ & 100 & $148.0 \pm 8.5$ & $20.3 \pm 1.2$ & $24.0 \pm 1.8$ \\
$\mathrm{CP} \mathrm{S}_{\mathrm{S}}(\mathrm{Mw} \leq 1 \mathrm{kDa})$ & 100 & $130.2 \pm 6.4$ & $58.0 \pm 3.1$ & $60.3 \pm 2.9$ \\
\hline
\end{tabular}

The molecular weight of peptides has a significant effect on the antioxidant activity [28]. It was evident that the peptides with smaller molecular weight revealed a stronger antioxidant activity 
(Figure 2), which was similar to the results of previous reports [29]. In addition, compared with those under $0 \mathrm{~W}$ of microwave power, the $\mathrm{OH}$. scavenging activities of $\mathrm{CP}_{\mathrm{L}}, \mathrm{CP}_{\mathrm{M}}$, and $\mathrm{CP}_{\mathrm{S}}$ under $250 \mathrm{~W}$ power were significantly improved. The reasons for this result may be: (1) microwave radiation probably exposed more cleavage sites of collagen for alkaline protease hydrolysis, resulting in an improvement in antioxidant activity of the peptides due to altered amino acid sequences of peptides; (2) the microwaves probably altered the amino acid sequence of the alkaline protease, resulting in a change in the cleavage site of alkaline protease.

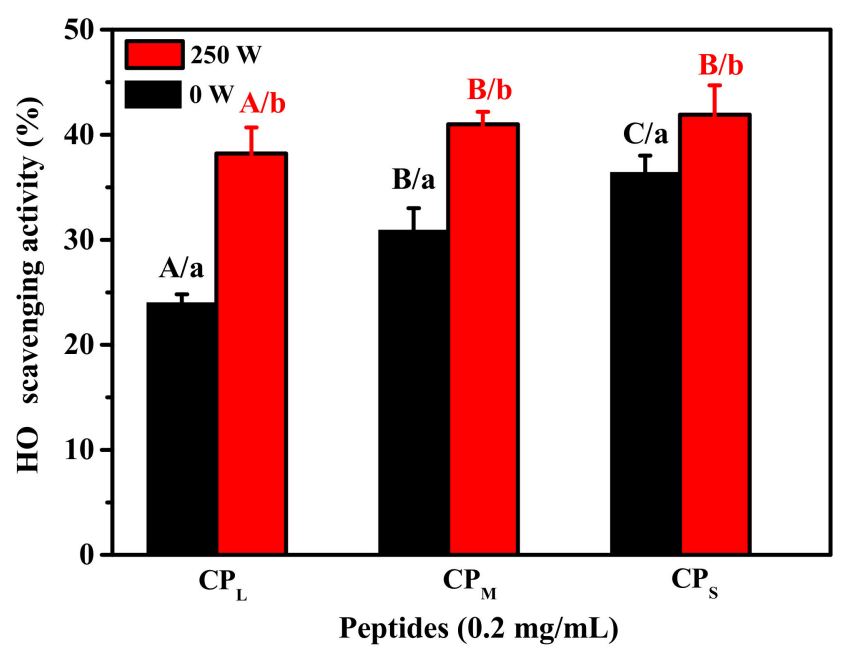

Figure 2. The $\mathrm{OH}$. scavenging activity of peptides with different $\mathrm{Mw}\left(\mathrm{CP}_{\mathrm{L}}, \mathrm{Mw}>5 \mathrm{kDa} ; \mathrm{CP}_{\mathrm{M}}, 1 \mathrm{kDa}\right.$ $<\mathrm{Mw} \leq 5 \mathrm{kDa} ; \mathrm{CP}_{\mathrm{S}}, \mathrm{Mw} \leq 1 \mathrm{kDa}$ ) from hydrolysate of ASC-Am. (a-b) Values with different letters indicated significant differences in the same samples at different microwave powers $(P<0.05)$. (A-C) Values with different letters indicated significant differences in different samples at the same microwave powers $(p<0.05)$.

\subsection{Antioxidant Activity of $C P_{S}$}

In order to better investigate its antioxidant properties, the DPPH and $\mathrm{OH}$. scavenging assays at different concentration of $\mathrm{CP}_{\mathrm{S}}$ were studied and compared with the positive controls containing ascorbic acid (AA). The $\mathrm{CP}_{\mathrm{S}}$ The $\mathrm{OH}$. scavenging activity of $\mathrm{CP}_{\mathrm{S}}$ increased from $24.9 \%$ at $0.1 \mathrm{mg} / \mathrm{mL}$ to $93.1 \%$ at $1.0 \mathrm{mg} / \mathrm{mL}$ (Figure $3 \mathrm{~A}$ ), indicating it scavenged $\mathrm{OH}$. in a concentration-dependent manner. The $\mathrm{EC}_{50}$ value of $\mathrm{CP}_{\mathrm{S}}$ was $0.4 \mathrm{mg} / \mathrm{mL}$ for $\mathrm{OH}$, which was lower than that of the peptide BSH-III (Mw $\leq 1 \mathrm{kDa})$ from protein hydrolysate obtained from bluefin leatherjacket skin $\left(\mathrm{IC}_{50}\right.$ of $\left.0.746 \mathrm{mg} / \mathrm{mL}\right)$ [30]. It is known that $\mathrm{OH}$. can have a destructive effect on many biological macromolecules, such as proteins and nucleic acids; therefore, the high $\mathrm{OH}$ - scavenging activity of $\mathrm{CP}_{\mathrm{S}}$ suggested the potential utilization of $\mathrm{CP}_{\mathrm{S}}$ as a natural antioxidant for reducing or eliminating damage induced by $\mathrm{OH}$. in food and pharmaceutical applications. 

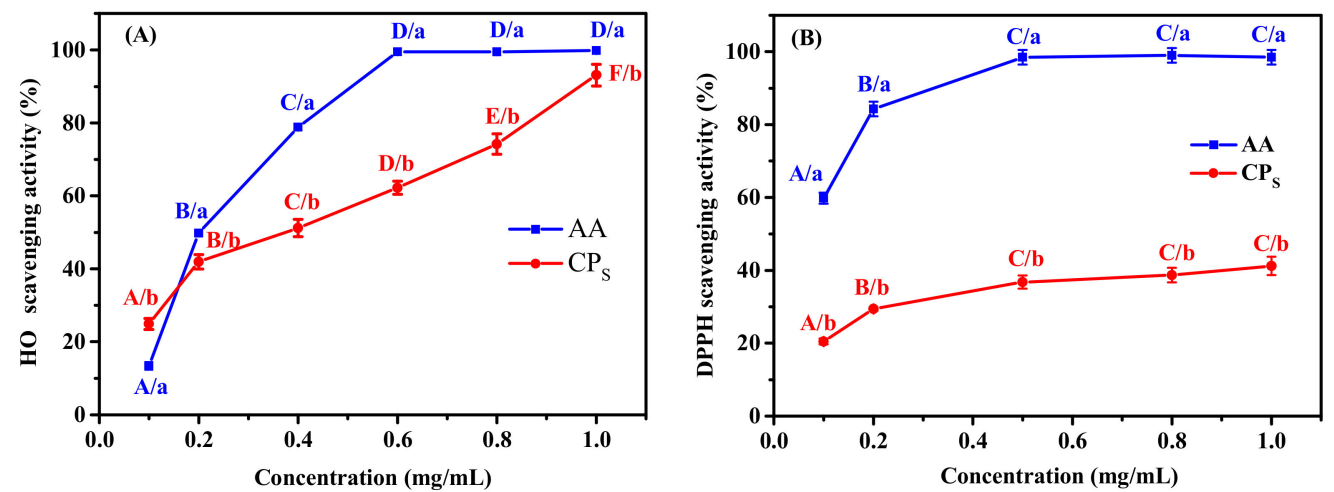

Figure 3. The scavenging activity of $\mathrm{OH} \cdot(\mathbf{A})$ and $\mathrm{DPPH}(\mathbf{B})$ of $\mathrm{CP}_{\mathrm{S}}$ obtained by alkaline protease hydrolysis of ASC-Am at $250 \mathrm{~W}$ of microwave power. Ascorbic acid (AA) was used as a positive control. $(a-b)$ Values with different letters indicated significant differences in different samples at the same concentrations $(p<0.05)$. (A-F) Values with different letters indicated significant differences in the same samples at the different concentrations $(p<0.05)$.

DPPH radicals are often used in antioxidant experiments because of their high stability [31]. The mechanism of DPPH assay is based on the reduction of DPPH solution in the presence of a hydrogen donor, leading to the formation of the non-radical form DPPH-H [32]. The scavenging of DPPH radicals by $\mathrm{CP}_{\mathrm{S}}$ was well correlated with the concentration of $\mathrm{CP}_{\mathrm{S}}$ (Figure 3B). The DPPH scavenging activity of $\mathrm{CP}_{\mathrm{S}}$ was found to be $20.5 \%$ at a concentration of $0.1 \mathrm{mg} / \mathrm{mL}$, which increased to $41.2 \%$ at $1.0 \mathrm{mg} / \mathrm{mL}$, still much lower than that of AA. However, the DPPH scavenging activity of $\mathrm{CP}_{\mathrm{S}}$ was significantly higher than that of the protein hydrolysate fraction $(\mathrm{Mw}<1 \mathrm{kDa})$ from bluefin leatherjacket skin and skate cartilage [30,33].

\subsection{Antioxidant Activity Evaluated by $\mathrm{H}_{2} \mathrm{O}_{2}$-Induced Injury Cell Model}

\subsubsection{The Effect of $\mathrm{H}_{2} \mathrm{O}_{2}$ and CPs on the Proliferation of RAW264.7 Cells}

To investigate the effect of $\mathrm{H}_{2} \mathrm{O}_{2}$ on viability of RAW264.7 cells, they were treated with different concentrations of $\mathrm{H}_{2} \mathrm{O}_{2}$. RAW264.7 cells revealed a significant decrease in viability with increasing concentration of $\mathrm{H}_{2} \mathrm{O}_{2}$ and treatment time (Figure 4). When the concentration of $\mathrm{H}_{2} \mathrm{O}_{2}$ was greater than $300 \mu \mathrm{M}$ and the treatment time was longer than $8 \mathrm{~h}$, the cell viability was significantly inhibited. Cell viability exposed to $500 \mu \mathrm{mol} / \mathrm{L} \mathrm{H}_{2} \mathrm{O}_{2}$ for $8 \mathrm{~h}$ was $46.2 \%$ of the control value. In the subsequent experiments, the RAW264.7 cells were treated with $500 \mu \mathrm{mol} / \mathrm{L} \mathrm{H}_{2} \mathrm{O}_{2}$ for $8 \mathrm{~h}$ to study the effect of $\mathrm{CP}_{S}$ on $\mathrm{H}_{2} \mathrm{O}_{2}$-induced injury. 


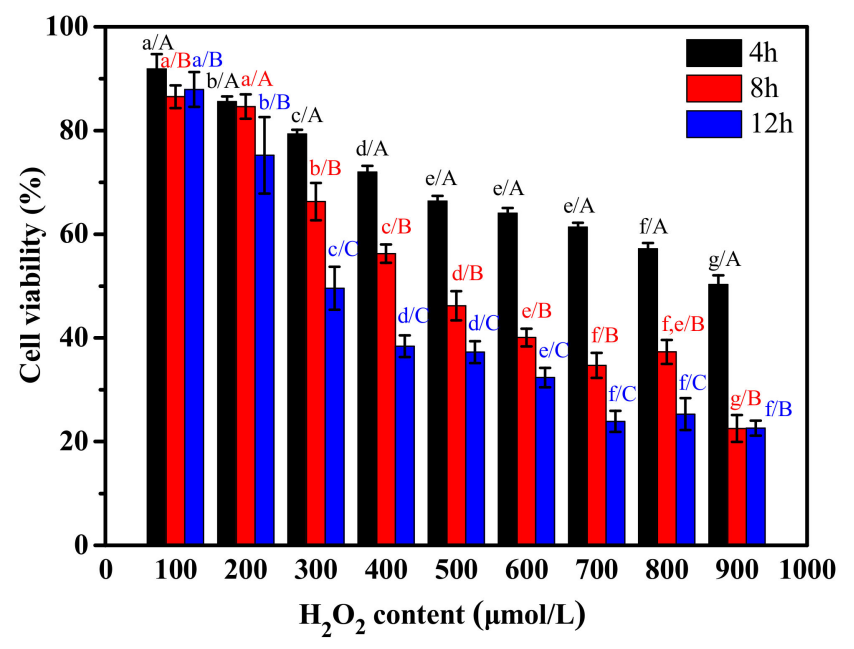

Figure 4. The effect of $\mathrm{H}_{2} \mathrm{O}_{2}$ on the viability of RAW264.7 cells. (a-g). Values with different letters indicated significant differences in the same time at different concentrations of $\mathrm{H}_{2} \mathrm{O}_{2}(p<0.05)$. (A-C) Values with different letters indicated significant differences in the same concentrations of $\mathrm{H}_{2} \mathrm{O}_{2}$ at different times $(p<0.05)$.

The effect of $\mathrm{CP}_{\mathrm{S}}$-treated on the proliferation of RAW264.7 cells was shown in Figure 5. The viability of RAW264.7 cells in $\mathrm{CP}_{\mathrm{S}}$ treatment group was significantly improved compared to the control group when the concentration of $\mathrm{CP}_{\mathrm{S}}$ increased from $20 \mu \mathrm{g} / \mathrm{mL}$ to $150 \mu \mathrm{g} / \mathrm{mL}$ (Figure 5). This demonstrated that $\mathrm{CP}_{\mathrm{S}}$ could effectively promote the proliferation of RAW264.7 cells in a dose-dependent manner. However, a significant increase in cell viability was not observed when cells were treated with $200 \mu \mathrm{g} / \mathrm{mL}$. Therefore, $100 \mu \mathrm{g} / \mathrm{mL}, 150 \mu \mathrm{g} / \mathrm{mL}$ and $200 \mu \mathrm{g} / \mathrm{mL}$ were selected as the low-, middle- and high-dose groups for subsequent experiments, respectively.

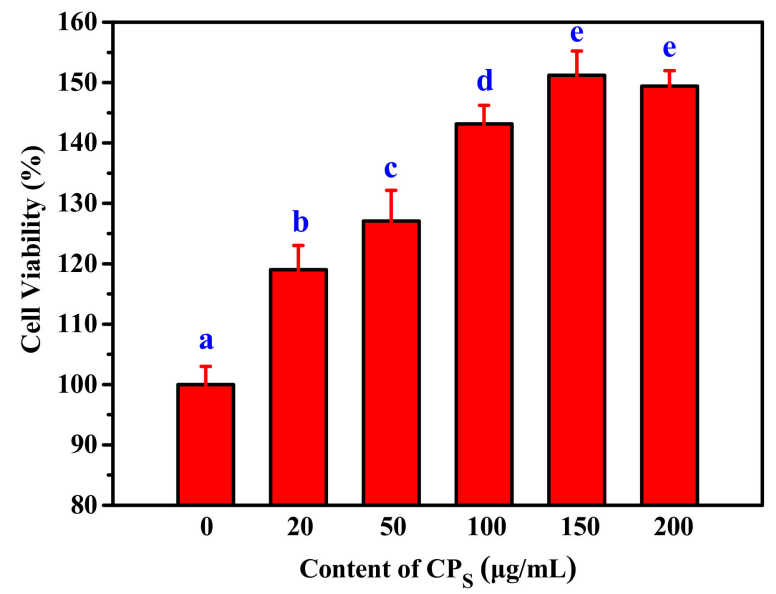

Figure 5. Effect of $\mathrm{CP}_{\mathrm{S}}$ on viability of RAW264.7 cells. Values with different letters are significantly different $(p<0.05)$.

\subsubsection{Effects of $\mathrm{CP}_{\mathrm{S}}$ on the ROS Levels in RAW264.7 Cells}

In this section, the effect of $\mathrm{CP}_{\mathrm{S}}$ on the ROS levels in RAW264.7 cells was investigated. The fluorescence intensity in RAW264.7 following $\mathrm{H}_{2} \mathrm{O}_{2}$ treatment was significantly larger than that of the control group (Figure 6). However, the addition of $\mathrm{CP}_{\mathrm{S}}$ effectively reduced the ROS level relative to the model group, and the ROS level gradually decreased with the increase in $\mathrm{CP}_{\mathrm{S}}$ concentration. The results suggested that the protective effects of $\mathrm{CP}_{\mathrm{S}}$ against $\mathrm{H}_{2} \mathrm{O}_{2}$-induced injury of RAW264.7 cells may have resulted from inhibition of intracellular ROS production. 


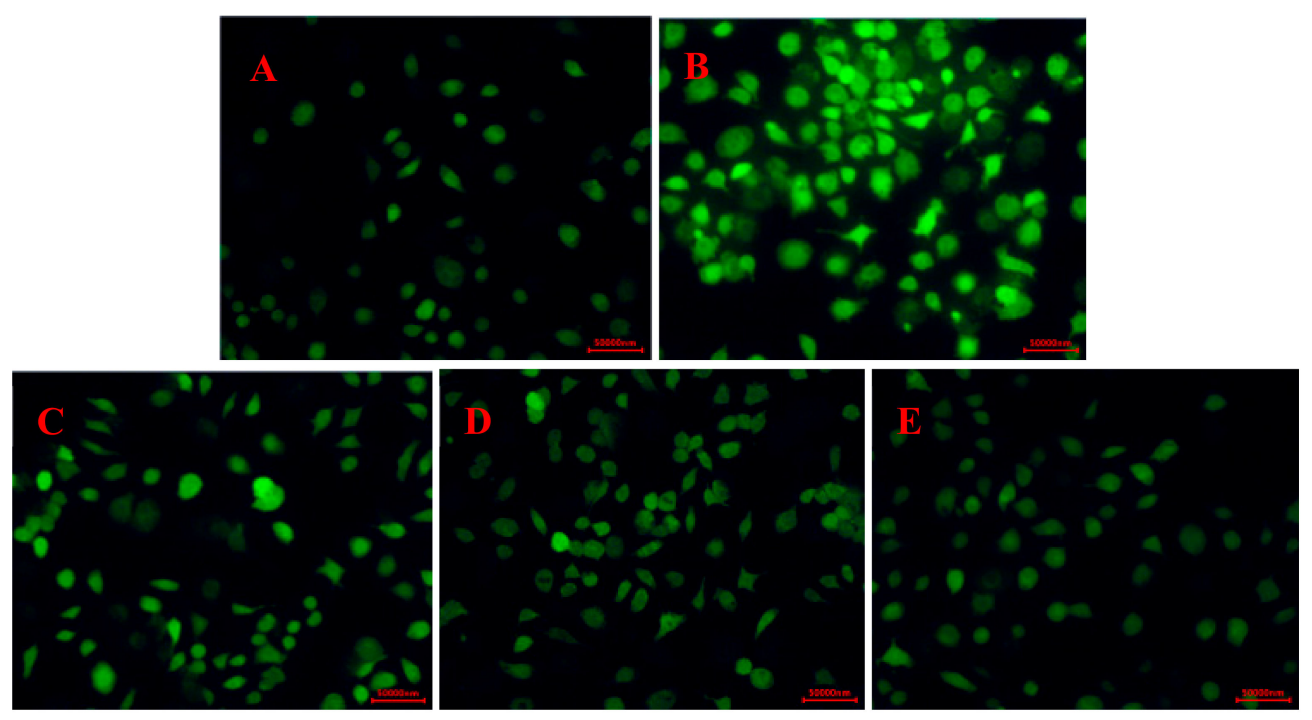

Figure 6. Effect of $\mathrm{CP}_{\mathrm{S}}$ on ROS levels in RAW264.7 cells induced by $\mathrm{H}_{2} \mathrm{O}_{2}$. (A) Control group; (B) model group (500 $\left.\mu \mathrm{M} \mathrm{H}_{2} \mathrm{O}_{2}\right)$; (C) low-dose group $\left(100 \mu \mathrm{g} / \mathrm{mL} \mathrm{CP}_{\mathrm{S}}+500 \mu \mathrm{M} \mathrm{H}_{2} \mathrm{O}_{2}\right)$; (D) middle-dose group $\left(150 \mu \mathrm{g} / \mathrm{mL} \mathrm{CP} \mathrm{S}+500 \mu \mathrm{M} \mathrm{H}_{2} \mathrm{O}_{2}\right)$; (E) high-dose group $\left(200 \mu \mathrm{g} / \mathrm{mL} \mathrm{CP}_{\mathrm{S}}+500 \mu \mathrm{M} \mathrm{H}_{2} \mathrm{O}_{2}\right)$.

\subsubsection{Effect of $\mathrm{CP}_{\mathrm{S}}$ on the Level of MDA, SOD, and GSH-Px in Cells}

To evaluate the antioxidant activity of $\mathrm{CP}_{\mathrm{S}}$, we investigated the effect of $\mathrm{CP}_{\mathrm{S}}$-pretreated on the level of MDA, GSH-Px, and SOD respectively in $\mathrm{H}_{2} \mathrm{O}_{2}$-induced oxidative damage of RAW264.7 cells. The MDA level in the cells significantly increased following $\mathrm{H}_{2} \mathrm{O}_{2}$ treatment as compared to the control group (Figure 7A), indicating that the RAW264.7 cells were damaged by $\mathrm{H}_{2} \mathrm{O}_{2}$. A significantly lower MDA level compared to the control group was observed in the $\mathrm{CP}_{\mathrm{S}}$-treated groups, especially in the middle- and high-dose group, indicating that $\mathrm{CP}_{\mathrm{S}}$ decreased the oxidative damage level of cells caused by $\mathrm{H}_{2} \mathrm{O}_{2}$. Effects of $\mathrm{CP}_{\mathrm{S}}$ on GSH-Px and SOD activity of RAW264.7 cells were shown in Figure 7B,C. The results showed that $\mathrm{H}_{2} \mathrm{O}_{2}$ caused a significant decrease in GSH-Px and SOD activity in RAW264.7 cells. Fortunately, the levels of GSH-Px and SOD were both markedly promoted in $\mathrm{CP}_{\mathrm{S}}$-treated groups as compared to the control group. The group with the higher dose exhibited the highest level of GSH-Px, but the results between the low-dose and middle-dose groups were not statistically significant. The highest levels of SOD were observed in the high-dose and middle-dose groups, but the difference between them was not statistically significant. Qiu et al. had reported that collagen peptides could up-regulate the levels of SOD and GSH-Px, and down-regulate the contents of MDA, playing a protective role in antioxidant effects on Drosophila [34]. The collagen peptides from cod skin protected liver tissue against oxidative injure by increasing the activity of SOD and decreasing MDA [35]. Therefore, these results in this study demonstrated that collagen peptides from sea cucumber Acaudina molpadioides could protect RAW264.7 cells against $\mathrm{H}_{2} \mathrm{O}_{2}$-induced injury by inhibition of lipid peroxides and enhancement of antioxidant enzyme activity. 

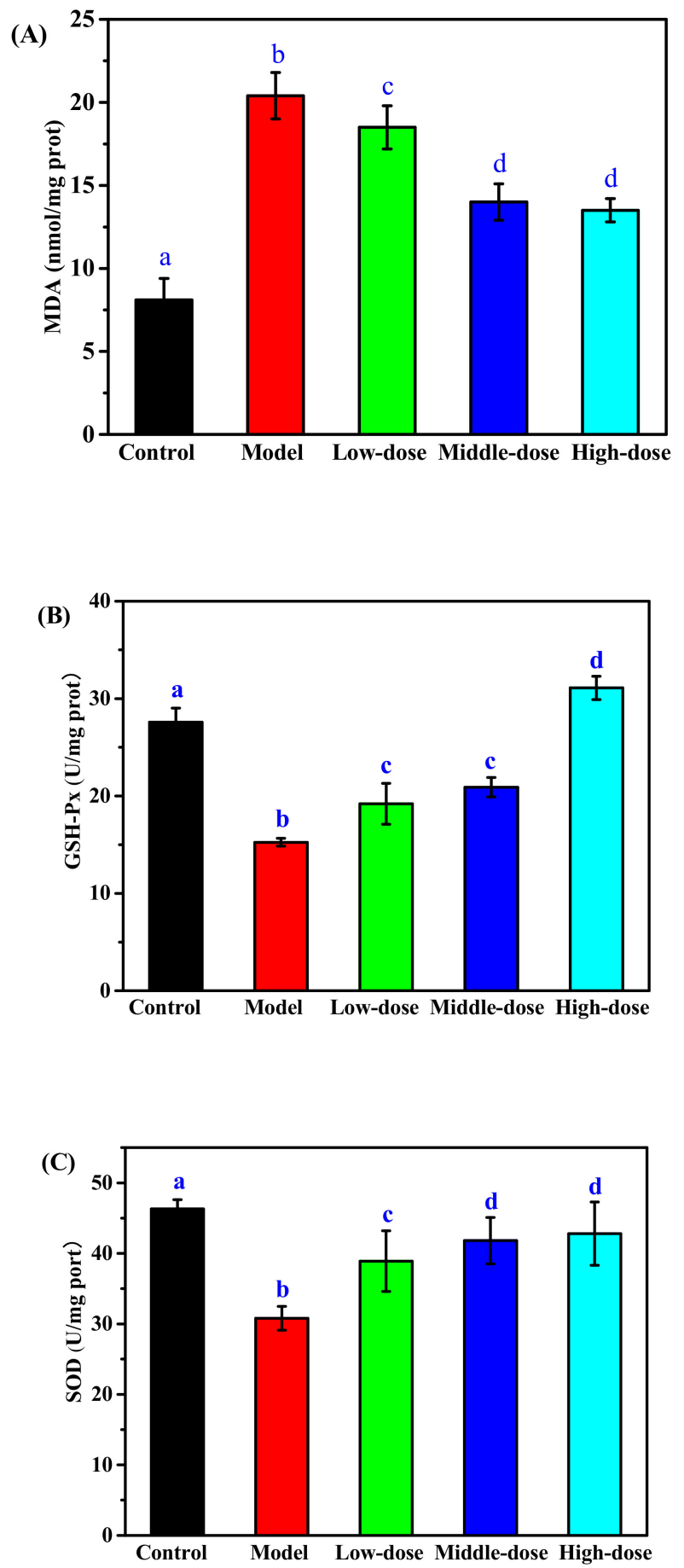

Figure 7. Effect of $\mathrm{CP}_{\mathrm{S}}$ on levels of MDA (A), GSH-Px (B), and SOD (C) in RAW264.7 cells induced by $\mathrm{H}_{2} \mathrm{O}_{2}$. Model group (500 $\left.\mu \mathrm{M} \mathrm{H}_{2} \mathrm{O}_{2}\right)$, low-dose group $\left(100 \mu \mathrm{g} / \mathrm{mL} \mathrm{CP}_{\mathrm{S}}+500 \mu \mathrm{M} \mathrm{H}_{2} \mathrm{O}_{2}\right)$, middle-dose group $\left(150 \mu \mathrm{g} / \mathrm{mL} \mathrm{CP} P_{\mathrm{S}}+500 \mu \mathrm{M} \mathrm{H}_{2} \mathrm{O}_{2}\right)$, high-dose group $\left(200 \mu \mathrm{g} / \mathrm{mL} \mathrm{CP} \mathrm{P}_{\mathrm{S}}+500 \mu \mathrm{M} \mathrm{H}_{2} \mathrm{O}_{2}\right)$. Values with different letters are significantly different $(p<0.05)$.

\section{Materials and Methods}

\subsection{Chemicals and Reagents}

Sea cucumber Acaudina molpadioides was provided from Zhoushan Jingzhou Aquatic Food Co., Ltd., in Zhejiang Province of China. Fetal calf serum was provided by GIBCO (Invitrogen Corporation, Carlsbad, California, USA). The 2,2-dipehnyl-1-picryldydrazyl (DPPH), 3-(4,5- 
Dimethylthiazol-2-yl)-2,5-diphenyl tetrazolium bromide (MTT) and dimethyl sulfoxide (DMSO) were purchased from Sigma-Aldrich (Shanghai, China). Assay kits for the MDA, SOD, and GSH-Px were purchased from the Nanjing Jiancheng Bioengineering Institute (Nanjing, China). ROS detection kit was purchased from Beyotime Company (Jiangsu, China). All other reagents were analytical grade.

\subsection{Preparation of Collagen Peptides}

ASC-Am was prepared from the body wall of Acaudina molpadioides according to the method reported previously [26]. Two grams of ASC-Am were added into $200 \mathrm{~mL}$ buffer solution (pH 10.0) and pretreated with irradiation $(0,50,150,200,250$, and $300 \mathrm{~W})$ for 30 minutes each in a microwave (XH-300A; Beijing Xianghu, China). Alkaline protease ( $\geq 200 \mathrm{U} / \mathrm{mg}$, Shanghai Ryon Biological Technology Co., Ltd., Shanghai, China) was added to the sample for hydrolysis at $45^{\circ} \mathrm{C}$. After $1 \mathrm{~h}$, the alkaline protease was inactivated in boiling water for $10 \mathrm{~min}$. After centrifuging the hydrolysates at 10,000 rpm for $10 \mathrm{~min}$, the supernatants were freeze-dried, and the scavenging activity of hydroxyl radical $(\mathrm{OH} \cdot)$ was measured at the concentration of $0.2 \mathrm{mg} / \mathrm{mL}$.

The hydrolysates obtained under the optimal microwave power were separated by ultrafiltration membranes with size exclusion of $5 \mathrm{kDa}$ and $1 \mathrm{kDa}$. Three fractions $\left(\mathrm{CP}_{\mathrm{S}}\right.$, collagen peptides with $\mathrm{Mw}$ $\leq 1 \mathrm{kDa} ; \mathrm{CP}_{\mathrm{M}}$, collagen peptides with $1 \mathrm{kDa}<\mathrm{Mw} \leq 5 \mathrm{kDa}$; and $\mathrm{CP}_{\mathrm{L}}$, collagen peptides with $\mathrm{Mw}>$ $5 \mathrm{kDa}$ ) were collected and freeze-dried separately to measure the peptide content and scavenging activity of $\mathrm{OH}$. radical at the concentration of $0.2 \mathrm{mg} / \mathrm{mL}$.

\subsection{Antioxidant Activity Measurements}

\subsubsection{Scavenging Activity of Hydroxyl Radical}

The scavenging activity of $\mathrm{OH} \cdot$ of peptide was determined using the Fenton method [36]. Two $\mathrm{mL}$ peptide samples were mixed with $2 \mathrm{~mL}$ of phosphate buffer $(0.2 \mathrm{M}, \mathrm{pH} 7.4), 1 \mathrm{~mL}$ of 1,10-phenanthroline $(0.75 \mathrm{mM}), 1 \mathrm{~mL}$ of $\mathrm{FeSO}_{4}(0.75 \mathrm{mM})$, and $1 \mathrm{~mL}$ of $0.3 \% \mathrm{H}_{2} \mathrm{O}_{2}(\mathrm{v} / \mathrm{v})$. The mixture was heated at $37^{\circ} \mathrm{C}$ for $30 \mathrm{~min}$, and the absorbance $\left(\mathrm{A}_{1}\right)$ measured at $510 \mathrm{~nm}$. The scavenging activity of $\mathrm{OH} \cdot$ was calculated using the following formula, where $\mathrm{A}_{0}$ is the absorbance of the blank with $2 \mathrm{~mL}$ of water instead of the peptide solution and $\mathrm{A}_{2}$ the absorbance of mixture with $1 \mathrm{~mL}$ of deionized water instead of the $\mathrm{FeSO}_{4}$ solution.

$$
\mathrm{OH} \cdot \text { scavenging activity }(\%)=\left[1-\left(\mathrm{A}_{1}-\mathrm{A}_{2}\right) / \mathrm{A}_{0}\right] \times 100 \%
$$

\subsubsection{Scavenging Activity of DPPH Radical}

The scavenging activity of DPPH radical was tested according to previously reported methods [37]. The samples of peptides were dissolved in water with different concentrations $0.1,0.2,0.5,0.8$, and $1.0 \mathrm{mg} / \mathrm{mL}$. Two $\mathrm{mL}$ of peptide samples were mixed with $2 \mathrm{~mL}$ of DPPH solution $(0.2 \mathrm{mM})$ and $1 \mathrm{~mL}$ of ethanol. The mixture was incubated for $30 \mathrm{~min}$ at room temperature and then centrifuged at $5000 \mathrm{rpm}$ for $5 \mathrm{~min}$. The absorbance of the sample $\left(\mathrm{A}_{\mathrm{s}}\right)$ was measured at $517 \mathrm{~nm}$ using an ultraviolet-visible spectrophotometer. The scavenging activity of DPPH was calculated as shown in the formula:

$$
\text { DPPH scavenging activity }(\%)=\left[1-\left(\mathrm{A}_{\mathrm{s}}-\mathrm{A}_{\mathrm{b}}\right) / \mathrm{A}_{\mathrm{c}}\right] \times 100 \%
$$

where $A_{c}$ is the absorbance of the control group with $2 \mathrm{~mL}$ of water instead of the peptide sample; $A_{b}$ is the absorbance of blank with $2 \mathrm{~mL}$ of ethanol in place of the DPPH solution.

\subsection{The Effect of $\mathrm{H}_{2} \mathrm{O}_{2}$ and Peptides on the Proliferation of $\mathrm{RAW} 264.7$ Cells}

RAW264.7 cells (purchased from Chinese Academy of Sciences) were grown in DMEM medium supplemented with $10 \%$ fetal bovine serum and incubated at $37^{\circ} \mathrm{C}$ in a humidified atmosphere with $5 \% \mathrm{CO}_{2}$. The peptides were dissolved in DMEM medium and diluted to different concentrations 
$(20-200 \mu \mathrm{g} / \mathrm{mL})$. Cell viability was determined using MTT assay. RAW264.7 cells were seeded in 96-well plates at $1 \times 10^{5}$ cells $/ \mathrm{mL}$ and incubated at $37^{\circ} \mathrm{C}$ with $5 \% \mathrm{CO}_{2}$ for $24 \mathrm{~h}$. The cells were treated with different concentrations of $\mathrm{H}_{2} \mathrm{O}_{2}(100,200,300,400,500,600,700,800$, and $900 \mu \mathrm{mol} / \mathrm{L})$ or peptides. A volume of $20 \mu \mathrm{L}$ of MTT solution $(2 \mathrm{mg} / \mathrm{mL}$ ) was added to each well and incubated for $4 \mathrm{~h}$. The supernatant was removed and $100 \mu \mathrm{L}$ of Dimethyl sulfoxide (DMSO) was added into each well to dissolve the formazan crystals. The plates were shaken for $5 \mathrm{~min}$ to dissolve the crystals completely, and absorbance was measured at $490 \mathrm{~nm}$. The cell viability with $\mathrm{H}_{2} \mathrm{O}_{2}$ or peptide treatment was evaluated as follows:

$$
\text { Cell viability }(\%)=\mathrm{A}_{\mathrm{S}} / \mathrm{A}_{\mathrm{N}} \times 100 \%
$$

where $A_{S}$ and $A_{N}$ were the absorbance of treatment and control wells, respectively.

\subsection{Reactive Oxygen Species (ROS) Assay}

Production of ROS was monitored using a ROS Assay Kit (Beyotime Biotechnology Co., Ltd., Shanghai, China). RAW 264.7 cells were cultured in 96-well plates with a density of $1 \times 10^{5}$ cells $/ \mathrm{mL}$ for $24 \mathrm{~h}$. Cells were treated with various concentrations of peptides for $24 \mathrm{~h}$, and then exposed to $\mathrm{H}_{2} \mathrm{O}_{2}(500 \mu \mathrm{mol} / \mathrm{L})$ for $8 \mathrm{~h}$. The experiments were implemented in the control group (not treated with peptides and $\mathrm{H}_{2} \mathrm{O}_{2}$ ), the model group (treated with $500 \mu \mathrm{M} \mathrm{H}_{2} \mathrm{O}_{2}$ ), the low-dose group (treated with $100 \mu \mathrm{g} / \mathrm{mL}$ peptides $+500 \mu \mathrm{M} \mathrm{H}_{2} \mathrm{O}_{2}$ ), the middle-dose group (treated with $150 \mu \mathrm{g} / \mathrm{mL}$ peptides + $500 \mu \mathrm{M} \mathrm{H}_{2} \mathrm{O}_{2}$ ), and the high-dose group (treated with $200 \mu \mathrm{g} / \mathrm{mL}$ peptides $+500 \mu \mathrm{M} \mathrm{H}_{2} \mathrm{O}_{2}$ ). RAW264.7 were incubated for $20 \mathrm{~min}$ in a $37^{\circ} \mathrm{C}$ cell incubator with $5 \mu \mathrm{L} 2^{\prime}, 7^{\prime}$ - dichlorodihydrofluorescein diacetate (DCFH-DA). Cells were washed three times with serum-free cell culture medium and then observed under a fluorescence microscope.

\subsection{Assays for Antioxidant Enzyme Activity}

RAW264.7 cells $\left(1 \times 10^{5}\right.$ cells $\left./ \mathrm{mL}\right)$ were seeded in 96-well plates, and exposed to $500 \mu \mathrm{mol} / \mathrm{L} \mathrm{H}_{2} \mathrm{O}_{2}$ for $8 \mathrm{~h}$ with or without various concentrations of peptide pre-treatment for $24 \mathrm{~h}$. RAW264.7 cells were washed with Phosphate-buffered saline (PBS), and then lysed with cell lysate. The supernatants were collected following centrifugation at $2000 \times g$ for $5 \mathrm{~min}$ at $4{ }^{\circ} \mathrm{C}$. The activity of SOD, GSH-Px, and MDA content was determined by using corresponding diagnostic kits according to the manufacturer's instructions (Nanjing Jiancheng Bioengineering Institute, Nanjing, China).

\subsection{Statistical Analysis}

Each experiment was carried out in triplicate. Data were presented as means and standard deviations. Results were analyzed using Microsoft Excel 2010 (Redmond, WA, USA), and significant differences $(p<0.05)$ between data were identified by Duncan's multiple range test in the software SPSS (SPSS Inc., Chicago, IL, USA).

\section{Conclusions}

Microwave-assisted hydrolysis of collagen is a promising method for preparation of antioxidant peptides. Microwave radiation can significantly increase the content and antioxidant activity of small molecular weight peptides. The hydrolyzate fragment $\mathrm{CP}_{\mathrm{S}}(\mathrm{Mw} \leq 1 \mathrm{kDa})$ obtained by microwave-assisted alkaline protease hydrolysis of collagen from sea cucumber Acaudina molpadioides exhibited the good scavenging activities of $\mathrm{DPPH}$ and $\mathrm{OH} \bullet \cdot \mathrm{CP}_{\mathrm{S}}$ also exhibited a significant protective effect on $\mathrm{H}_{2} \mathrm{O}_{2}$-injured RAW264.7 cells by promoting cell proliferation, reducing the levels of ROS and MDA, and enhancing antioxidant enzyme (SOD and GSH-Px) activity. Therefore, it is recommended, as a result of the current study, to explore $\mathrm{CP}_{\mathrm{S}}$ as a potential natural antioxidant and utilize microwave-assisted hydrolysis as a method of obtaining high levels of antioxidant peptides from naturally occurring high-molecular weight protein molecules. 
Author Contributions: H.-X.J. designed the experiments and wrote the paper; Y.L. performed the experiments; J.L. analyzed the data; S.-J.L. and Z.-S.Y. provided experimental materials and equipment.

Funding: The research was funded by the Fundamental Research Funds for the Provincial Universities of Zhejiang Province (2019JZ00005) and Natural Science Foundation of Zhejiang province (LQ20D060004).

Conflicts of Interest: The authors declare no conflict of interest. The funders had no role in the design of the study; in the collection, analyses, or interpretation of data; in the writing of the manuscript, or in the decision to publish the results.

\section{References}

1. Liu, R.; Zheng, W.; Li, J.; Wang, L.; Wu, H.; Wang, X.; Shi, L. Rapid identification of bioactive peptides with antioxidant activity from the enzymatic hydrolysate of Mactra veneriformis by UHPLC-Q-TOF mass spectrometry. Food Chem. 2015, 167, 484-489. [CrossRef] [PubMed]

2. Reyes Jara, A.M.; Liggieri, C.S.; Bruno, M.A. Preparation of soy protein hydrolysates with antioxidant activity by using peptidases from latex of Maclura pomifera fruits. Food Chem. 2018, 264, 326-333. [CrossRef] [PubMed]

3. Dinstel, R.R.; Cascio, J.; Koukel, S. The antioxidant level of Alaska's wild berries: High, higher and highest. Int. J. Circumpolar Health 2013, 72. [CrossRef]

4. $\quad$ Lin, X.; Bai, D.; Wei, Z.; Zhang, Y.; Huang, Y.; Deng, H.; Huang, X. Curcumin attenuates oxidative stress in RAW264.7 cells by increasing the activity of antioxidant enzymes and activating the Nrf2-Keap1 pathway. PLoS ONE 2019, 14, e216711. [CrossRef] [PubMed]

5. Li, S.; Song, Z.; Liu, T.; Liang, J.; Yuan, J.; Xu, Z.; Sun, Z.; Lai, X.; Xiong, Q.; Zhang, D. Polysaccharide from Ostrea rivularis attenuates reproductive oxidative stress damage via activating Keap1-Nrf2/ARE pathway. Carbohydr. Polym. 2018, 186, 321-331. [CrossRef] [PubMed]

6. Xiao, X.; Liua, J.; Zhu, X.; Hua, Y.; Wang, C.; Zhang, Y. Protective effects of protopine on hydrogen peroxide-induced oxidative injury of PC12 cells via Ca antagonism and antioxidant mechanisms. Eur. J. Pharmacol. 2008, 591, 21-27. [CrossRef]

7. Duranti, G.; Ceci, R.; Sgrò, P.; Sabatini, S.; Luigi, L.D. Influence of the PDE5 inhibitor tadalafil on redox status and antioxidant defense system in C2C12 skeletal muscle cells. Cell Stress Chaperones 2017, 22, 389-396. [CrossRef]

8. Huang, Y.; Ruan, G.; Qin, Z.; Li, H.; Zheng, Y. Antioxidant activity measurement and potential antioxidant peptides exploration from hydrolysates of novel continuous microwave-assisted enzymolysis of the Scomberomorus niphonius protein. Food Chem. 2017, 223, 89-95. [CrossRef]

9. Zhong, M.; Chen, T.; Hu, C.; Ren, C. Isolation and characterization of collagen from the body wall of sea cucumber Stichopus monotuberculatus. J. Food Sci. 2015, 80, C671-C679. [CrossRef]

10. Zhang, J.; Liu, S.; Zhang, Y.; Lu, Y.; Wang, M.; Wang, G.; Liu, X. Purification and antioxidant ability of peptide from egg in sea cucumber Apostichopus japonicus. Int. J. Food Prop. 2016, 20, 306-317. [CrossRef]

11. Ferrario, C.; Leggio, L.; Leone, R.; Di Benedetto, C.; Guidetti, L.; Cocce, V.; Ascagni, M.; Bonasoro, F.; La Porta, C.A.M.; Candia Carnevali, M.D.; et al. Marine-derived collagen biomaterials from echinoderm connective tissues. Mar. Environ. Res. 2017, 128, 46-57. [CrossRef] [PubMed]

12. Wu, J.; Fujioka, M.; Sugimoto, K.; Mu, G.; Ishimi, Y. Assessment of effectiveness of oral administration of collagen peptide on bone metabolism in growing and mature rats. J. Bone Miner. Metab. 2004, 22,547-553. [CrossRef] [PubMed]

13. Ohara, H.; Iida, H.; Ito, K.; Takeuchi, Y.; Nomura, Y. Effects of Pro-Hyp, a collagen hydrolysate-derived peptide, on hyaluronic acid synthesis using in vitro cultured synovium cells and oral ingestion of collagen hydrolysates in a guinea pig model of osteoarthritis. Biosci. Biotechnol. Biochem. 2010, 74, 2096-2099. [CrossRef] [PubMed]

14. Midori, T.; Yoh-Ichi, K.; Yoshihiro, N.J.B.B. Biochemistry, effects of collagen peptide ingestion on UV-B-induced skin damage. Biosci. Biotechnol. Biochem. 2009, 73, 930-932.

15. Izquierdo, F.J.; Peñas, E.; Baeza, M.L.; Gomez, R. Effects of combined microwave and enzymatic treatments on the hydrolysis and immunoreactivity of dairy whey proteins. Int. Dairy J. 2008, 18, 918-922. [CrossRef] 
16. Xu, Z.; Fang, Y.; Chen, Y.; Yang, W.; Ma, N.; Pei, F.; Kimatu, B.M.; Hu, Q.; Qiu, W. Protective effects of Se-containing protein hydrolysates from Se-enriched rice against $\mathrm{Pb}(2+)$-induced cytotoxicity in $\mathrm{PC} 12$ and RAW264.7 cells. Food Chem. 2016, 202, 396-403. [CrossRef]

17. Lin, Y.J.; Le, G.W.; Wang, J.Y.; Li, Y.X.; Shi, Y.H.; Sun, J. Antioxidative peptides derived from enzyme hydrolysis of bone collagen after microwave assisted acid pre-treatment and nitrogen protection. Int. J. Mol. Sci. 2010, 11, 4297-4308. [CrossRef]

18. Zhang, H.; Yu, L.; Yang, Q.; Sun, J.; Bi, J.; Liu, S.; Zhang, C.; Tang, L. Optimization of a microwave-coupled enzymatic digestion process to prepare peanut peptides. Molecules 2012, 17, 5661-5674. [CrossRef]

19. Abedin, M.Z.; Karim, A.A.; Ahmed, F.; Latiff, A.A.; Gan, C.Y.; Che, G.F.; Islam Sarker, M.Z. Agriculture, isolation and characterization of pepsin-solubilized collagen from the integument of sea cucumber (Stichopus vastus). J. Sci. Food Agric. 2013, 93, 1083-1088. [CrossRef]

20. Lin, S.J.; Xue, Y.P.; San, E.L.; Keong, T.C.; Chen, L.F.; Zheng, Y.G. Extraction and characterization of pepsin soluble collagen from the body wall of sea cucumber Acaudina leucoprocta. J. Aquat. Food Prod. Technol. 2017, 26, 502-515. [CrossRef]

21. Liu, Z.; Oliveira, A.C.; Su, Y.C. Purification and characterization of pepsin-solubilized collagen from skin and connective tissue of giant red sea cucumber (Parastichopus californicus). J. Agric. Food Chem. 2010, 58, 1270-1274. [CrossRef] [PubMed]

22. Liu, Z.Q.; Tuo, F.Y.; Song, L.; Liu, Y.X.; Dong, X.P.; Li, D.M.; Zhou, D.Y.; Shahidi, F. Action of trypsin on structural changes of collagen fibres from sea cucumber (Stichopus japonicus). Food Chem. 2018, 256, 113-118. [CrossRef] [PubMed]

23. Zhu, B.W.; Dong, X.P.; Zhou, D.Y.; Gao, Y.; Yang, J.F.; Li, D.M.; Zhao, X.K.; Ren, T.T.; Ye, W.X.; Tan, H.; et al. Physicochemical properties and radical scavenging capacities of pepsin-solubilized collagen from sea cucumber Stichopus japonicus. Food Hydrocoll. 2012, 28, 182-188. [CrossRef]

24. Zhuang, Y.; Sun, L.; Zhao, X.; Wang, J.; Hou, H.; Li, B. Antioxidant and melanogenesis-inhibitory activities of collagen peptide from jellyfish (Rhopilema esculentum). J. Sci. Food Agric. 2009, 89, 1722-1727. [CrossRef]

25. Zhou, X. Technology, antioxidant peptides isolated from sea cucumber Stichopus Japonicus. Eur. Food Res. Technol. 2012, 234, 441-447. [CrossRef]

26. Jin, H.X.; Xu, H.P.; Li, Y.; Zhang, Q.W.; Xie, H. Preparation and evaluation of peptides with potential antioxidant activity by microwave assisted enzymatic hydrolysis of collagen from sea cucumber Acaudina molpadioides obtained from Zhejiang Province in China. Mar. Drugs 2019, 17, 169. [CrossRef]

27. Uluko, H.; Zhang, S.; Liu, L.; Tsakama, M.; Lu, J.; Lv, J. Effects of thermal, microwave, and ultrasound pretreatments on antioxidative capacity of enzymatic milk protein concentrate hydrolysates. J. Funct. Foods 2015, 18, 1138-1146. [CrossRef]

28. Chi, C.F.; Hu, F.Y.; Wang, B.; Li, Z.R.; Luo, H.Y. Influence of amino acid compositions and peptide profiles on antioxidant capacities of two protein hydrolysates from skipjack tuna (Katsuwonus pelamis) dark muscle. Mar. Drugs 2015, 13, 2580-2601. [CrossRef]

29. Kong, X.; Zhou, H.; Hua, Y. Preparation and antioxidant activity of wheat gluten hydrolysates (WGHs) using ultrafiltration membranes. J. Sci. Food Agric. 2008, 88, 920-926. [CrossRef]

30. Chi, C.-F.; Wang, B.; Hu, F.-Y.; Wang, Y.-M.; Zhang, B.; Deng, S.-G.; Wu, C.-W. Purification and identification of three novel antioxidant peptides from protein hydrolysate of bluefin leatherjacket (Navodon septentrionalis) skin. Food Res. Int. 2015, 73, 124-129. [CrossRef]

31. Ma, Y.L.; Zhu, D.Y.; Thakur, K.; Wang, C.H.; Wang, H.; Ren, Y.F.; Zhang, J.G.; Wei, Z.J. Antioxidant and antibacterial evaluation of polysaccharides sequentially extracted from onion ( Allium cepa L.). Int. J. Biol. Macromol. 2018, 111, 92-101. [CrossRef] [PubMed]

32. Bao, Y.; Zhao, M.; Shi, J.; Ning, Y.; Jiang, Y.J.F.C. Effect of ultrasonic treatment on the recovery and DPPH radical scavenging activity of polysaccharides from longan fruit pericarp. Food Chem. 2008, 106, 685-690.

33. Pan, X.; Zhao, Y.Q.; Hu, F.Y.; Wang, B. Preparation and identification of antioxidant peptides from protein hydrolysate of skate ( Raja porosa ) cartilage. J. Funct. Foods 2016, 25, 220-230. [CrossRef]

34. Qiu, W.; Chen, X.; Tian, Y.; Wu, D.; Du, M.; Wang, S. Protection against oxidative stress and anti-aging effect in Drosophila of royal jelly-collagen peptide. Food Chem. Toxicol. 2019, 110881. [CrossRef] [PubMed]

35. Han, Y.; Xie, J.; Gao, H.; Xia, Y.; Chen, X.; Wang, C. Hepatoprotective effect of collagen peptides from cod skin against liver oxidative damage in vitro and in vivo. Cell Biochem. Biophys. 2015, 71, 1089-1095. [CrossRef] [PubMed] 
36. Lu, C.; Li, H.; Li, C.; Chen, B.; Shen, Y. Chemical composition and radical scavenging activity of Amygdalus pedunculata Pall leaves' essential oil. Food Chem. Toxicol. 2018, 119, 368-374. [CrossRef]

37. Aissi, O.; Boussaid, M.; Messaoud, C. Essential oil composition in natural populations of Pistacia lentiscus L. from Tunisia: Effect of ecological factors and incidence on antioxidant and antiacetylcholinesterase activities. Ind. Crop. Prod. 2016, 91, 56-65. [CrossRef]

(C) 2019 by the authors. Licensee MDPI, Basel, Switzerland. This article is an open access article distributed under the terms and conditions of the Creative Commons Attribution (CC BY) license (http://creativecommons.org/licenses/by/4.0/). 